\title{
Measuring the contribution of higher education to innovation capacity in the EU
}

CHEPS WORKING PAPER 03/2016

Paul Benneworth. CHEPS (University of Twente)

p.benneworth@utwente.nl

Nadine Zeeman. CHEPS (University of Twente)

n.zeeman@utwente.nl

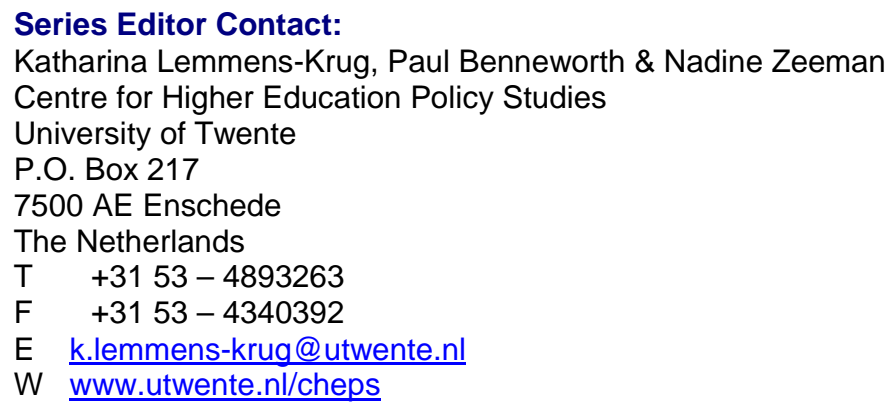




\section{Table of Contents}

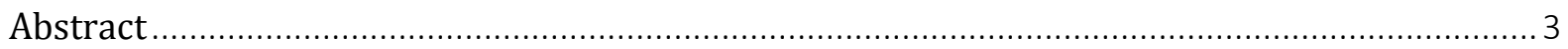

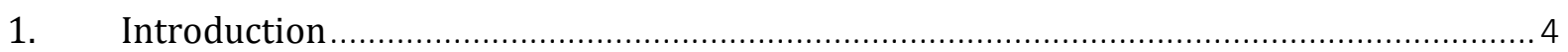

2. Challenges of higher education and relation to innovation ........................................ 4

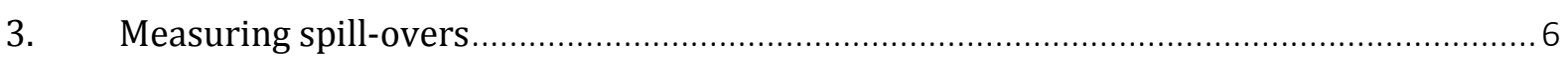

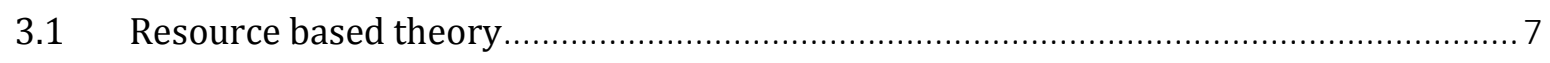

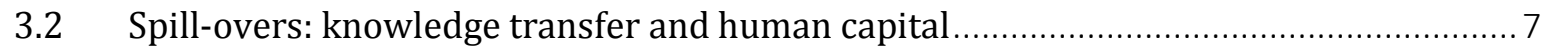

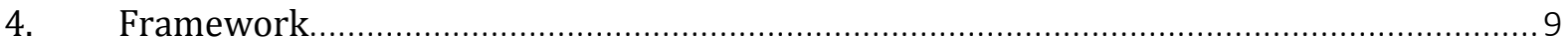

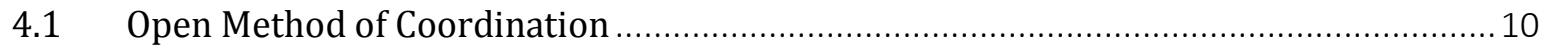

European Innovation Scoreboard .......................................................... 11

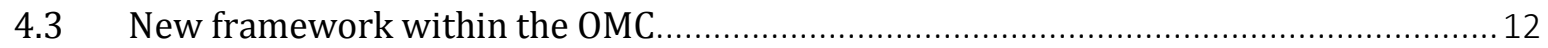

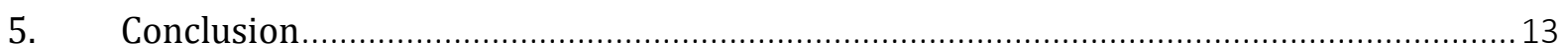

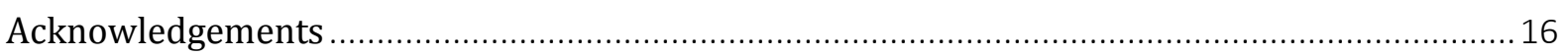

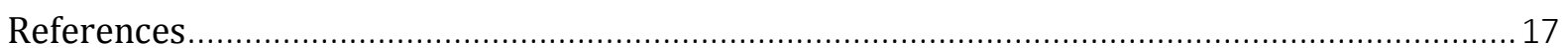




\begin{abstract}
There has been a massive expansion of higher education in recent decades as part of attempts to create workforces with the skills to be able to compete successfully in the context of the knowledge based economy. At the same time, there is widespread unrest that universities are failing to respond to these new demands and are continuing to act as 'ivory towers' outside of rather than driving forward society. A key challenge for European policy-makers is therefore distinguishing the extent to which universities are realising their potential to contribute to the emergence of the knowledge-based economy.

In this working paper we try to provide evidence on the key factors determining the contribution of higher education institutions (HEI) to innovation capabilities and expand the understanding of this contribution beyond traditional measures of the role of HEI on innovation capabilities. In this sense, we focus on the relevance of spill-overs through knowledge-transfer mechanisms as well as through human capital mechanisms.
\end{abstract}

Key words: contribution, human capital, indicators, innovation capacity, knowledge transfer, spill-overs, universities 


\section{Introduction}

Universities are increasingly expected to focus on innovation to meet the expectations of society. Higher education (HE) plays a significant role to contribute to social and economic development (Smart Specialization Platform, 2011, p.3). Actions and policies have been introduced with the objective to strengthen higher education institutions (HEIs) to serve the needs of the European society in an environment of global economic competition. In this regard, policy documents argue for more involvement of universities in innovation (David \& Metcalfe, 2007, p. 22). Within this context, policy makers are developing measures to determine the extent to which universities support innovation and innovation growth.

Several studies have tried to measure the contribution of universities to innovation by focusing on the second mission of universities, the research mission of universities (Veugelers, 2014). This traditional and underlying model for the analysis of the contribution of HEIs to innovation capabilities provides a framework that relates universities to innovation outputs.

This focus on the second mission of universities led to dissatisfaction because it provides only a limited view on the relation between universities and innovation. New processes and products are not only driven by research and development (R\&D) (David \& Metcalfe, 2007, p. 3). A one-sided view is presented by only emphasizing R\&D and framing this by primarily taking into account publications, licences, patenting and consultancy activities of universities (Izsak, Markianidou, Lukach \& Wastyn, 2013, p. 24-26).

In this working paper, we aim to discern what matters about the contribution of universities to innovation capacity. The capacity to innovate are also determined by other factors, such as teaching and education. To measure in an adequate way the contribution of universities to innovation capacity also these other factors should be taken into account. We need to understand that there are multiple channels through which universities can contribute to innovation capacity. There are numerous means to exchange knowledge between firms/business and universities (2015, p.13). This will be the basis for developing a better indicator set to improve the university contributions via the Open Method of Coordination (OMC).

Our new set of indicators has the aim to capture comprehensively the knowledge impact and quality of HEIs to contribute to the wider society (Interim report, 2015, p.3). We aim to discern the public value of $\mathrm{H}$ in this sense by determining the contribution of $\mathrm{HE}$ to innovation capacity to solve problems that are in the public interest.

\section{Challenges of higher education and relation to innovation}

One of the major challenges Europe potentially will be facing is a skills deficit. Figures provide evidence and information that there might be shortages of people that have the right qualifications in many areas of employment. By 2020, it is expected that we need an employment rate of around $74 \%$ to counter a possible shortage in the workforce. A potential skill gap is one of the reasons for the possible shortage. In this sense there is 
higher demand than supply of skills for several occupations, including for example ICT professionals, nurses and engineers. This will mean that large amounts of individuals will have difficulties in finding a job (CEDEFOP, 2008, p. 1; European Commission, n.d.).

During a time of economic crisis, it has been found that highly-skilled individuals have a better chance of finding a job. The OECD's Survey of Adult Skills found that education and skills increase employability and that if one sustains their skills, this can bring positive societal contributions in an economic and social perspective (European Commission, 2013, p. 3-4). These findings make a strong case that Europe should develop a strategy to meet to the demands of the knowledge-based economy. This provides for an important role to be played by education, training and lifelong learning.

HE already made attempts to respond to the challenge of a skills deficit. There has been a massive expansion of HE to create workforces that have the skills needed to be able to compete in the context of a knowledge based economy (Levy and Hopkins, 2010, p. 14). Still at this moment, the development of mass HE is high on the agendas of EU member states and the European Union (EU) (European Commission/EACEA/Eurydice, 2014, p.15). The context of the knowledge based economy is changing constantly and therefore continuously requires new kinds of skills to enable people to respond to continual labour market change (CEDEFOP, 2008, p.4).

$\mathrm{HE}$ and its links with research and innovation play significant role in providing the highly skilled human capital and to educate citizens that Europe needs to create jobs and economic growth. The EU strategy for modernising HE within the European Higher Education Area (EHEA) explicitly mentions the important role of HEIs in driving forward and maintain growth and links this to the role of HEIs in research and innovation. One of the five key priorities for $\mathrm{HE}$ is to strengthen the knowledge triangle by linking education, research and innovation (European Commission, 2011, p.2-3). HE and training systems are considered to be the key actors/responsible for improving the knowledge capital endowments by developing and maintaining the skills that are pre-conditions and drivers for smart growth and innovation (European Commission, 2013, p.3).

At the same time, there is unrest that universities are failing to responds to these new demands. Particular concern lies on perceptions that universities have tended to expand their existing activities rather than to create new courses, pedagogies, and learning environments that best meet these needs. This reduces the effectiveness of teaching and research to contribute to regional, social and or cultural development (Marmolejo \& Puukka, 2006). Some argue that we have reached a situation where reforms in HE have become predictable and that reforms tend to reproduce structures and processes familiar in other HE systems (Brennan, King \& Lebeau, 2004, p. 22).

These contradictions make it difficult for policy-makers to determine whether universities are driving or hindering innovation capacities. It is therefore a key challenge for European policy-makers to distinguish the extent to which universities are realising their potential to contribute to the emergence of the knowledge-based economy. By tackling this challenge, policy-makers can develop engagement stimuli to maximize these 
contributions and to optimize the returns that European societies receive from their public investments in HE (Interim report, 2015, p. 6).

It is therefore important to be able to analyse and measure in an appropriate fashion the way in which education, training and skills contribute to the capacity of society and the economy to innovate. The purpose of measuring university contribution to innovation capacity is to assist and support national HE policy makers towards a situation where legislation and framework optimise the contribution across European HE as a whole. The EC wants to raise the performance: increasing the contribution of European HE to innovation capacity to provide the human capital needed to increase the knowledge based-economy (European Commission, 2010).

\section{Measuring spill-overs}

Traditionally, one has been assessing the contribution of HE to innovation capacity from the second mission of HEIs. Most of the attention in the academic literature is focused inter alia on measures/indicators of academic (international) patenting, academic publications and licensing (Veugelers, 2014). Similarly, studies prepared for DG Research of the European Commission (EC) tend to focus on the second mission of HE and innovation capacities. Indicators as expenditure on research and development (e.g. R\&D and HERD) are used to determine the skilled human resources (Izsak, Markianidou, Lukach \& Wastyn, 2013, p. 24-26).

We take a different approach when determining the extent to which the HE sector is contributing to innovation capacity. Instead of focusing on patents and academic research publications, thus taking the perspective of R\&D, we try to approach the contribution of HE from a different angle. We look beyond traditional measures by including social and business activities of HEIs that are also a part of innovation (Interim report, 2-15, p.3).

As can be read in the previous section, HE is increasingly becoming linked to innovation policies (and the other way around). Nevertheless, there is not yet an updated understanding of the contribution of HE to innovation capacity, because the lack of evidence is hindering this development.

We try to identify the kinds of university-derived outputs that provide for activities which will expand innovators' access to the innovation resources. It is important to define the process by which universities specifically contribute to external resources for innovation in ways that improve innovation activities. We define universities contributing to innovative capacity via spill-over effects that make knowledge resources more readily available to innovators. We here understand that universities undertake particular activities that spill-over form the university activity into this knowledge pool and in this sense provide future innovation resources (Interim report, 2015, p. 8).

Previous attempts to measure spill-overs have proven to be extremely difficult. Most researchers recognized that you cannot measure spill-overs exactly, because there are no direct observables of, in our case, innovation flows (Garcia-Fontes \& Gonzales, 2004, p. 1). We therefore focus on measuring outputs that may later be connected with additional 
resources made available to innovators. We aim to identify data that can be collected that measure in some way those contributions. This enables us to better specify the research problem earlier stated, namely that there many measures available that focus on the direct contributions to innovation capacity (e.g. the second mission of HE), whereas the indirect contributions via the knowledge pool are less researched (the third mission of HE). Universities can either directly contribute to innovation capacity via individual transactions with current innovations, but they can also indirectly contribute via spillovers into the knowledge pool. It is important to acknowledge that universities have these multiple ways to contribute to innovation, and it is argued that in most cases the indirect support for innovation is equally and if not more important (Pillay, 2010, p. 49).

\subsection{Resource based theory}

Our focus is on spill-overs to determine the contributions of HE to innovation capacity. We aim to discern how universities generate knowledge externalities that could contribute to innovation capacity. We understand innovation as follows: several existing resources are combined to create a solution to a problem. Innovators seldom have all the resources that are needed to innovate successfully and do not always have the resources to acquire these resources to innovate on commercial terms. Spill-overs can therefore support firm to acquire access to these resources at different moments within the innovation process (Interim Report, 2015, p.8).

The resources of a firm can either be tangible or intangible. Tangible resources are resources that are owned by or belong to the firm, such as the building, whereas intangible resources are resources that can be accessed by the firm, such as the skills and expertise of the staff (Mills, Platts \& Bourne, 2003, p.149). The theory that applies these concepts definitions is the resource- based theory. In short, this theory considers a firm as set of tangible and intangible assets (Santema \& Van de Rijt, 1991, p. 53).

For our research, we are interested in these tangible and intangible resources that spillover from the universities to the firms and contribute to innovation capacity.

\subsection{Spill-overs: knowledge transfer and human capital}

Universities are involved in the creation, sharing and learning of knowledge. It is therefore essential to understand the different types of knowledge that exist to identify the knowledge externalities that spill-over from the university into the knowledge pool. The types of knowledge are typically divided into two types of knowledge: explicit and tacit knowledge. The first type refers to codified knowledge and the second type to noncodified knowledge or personal knowledge. Codified knowledge in HE can be technical or academic data/information and is documented and shared in formal languages like reports, books, patents and licenses (Smith, 2001, p. 315). Tacit knowledge is knowledge 'stored' in people, in their human mind, and is generated through experiences, education and jobs (Daud, Rahim \& Alimun, 2008, p.1).

Based on these two types of skills, we identify two type of spill-overs generated by universities that create resources and allow innovators to later exploit them. The first sort of spill-overs that occur when a piece of knowledge is transferred from within the university into a societal context. Here, it can be used as resource to fill an innovation 
shortage. This type of spill-overs are knowledge transfer spill-overs and relate to the codified type of knowledge. We identified three types of university activities where knowledge is transferred into society: 1) knowledge is transferred through a transaction (commercialisation), 2) the university and the innovated create together knowledge as an innovation input (academic engagement), and 3) the university strikes a chord with a non-innovator, that is an innovator is interested in it (it links to own work or life), and this could be an antecedent to innovation activities (public engagement) (Interim report, 2015, p. 10).

These three types can be further delineated to better understand the channels of knowledge exchange between universities and firms/businesses. The commercialisation of university-based research can take various forms and includes inter alia spin-offs and/or start-ups, academic involvement in patenting and providing the structures for technology transfer. With regard to academic engagement, this includes collaboration in R\&D projects and academic consulting, with the latter taking the form of a provision of a service by academics on commercial terms. The last type of knowledge exchange spillover, the public engagement activity of universities, is concerned with media engagement, societal engagement and education outreach. Universities can contribute to innovation by enforcing social creativity and cultural development that can be the basis for the expansion of the knowledge economy (Interim Report, 2015, p. 13-17, 19-22, 24).

The second type of spill-overs relates to non-codified knowledge/personal knowledge and we term this as human capital. This spill-over occurs when a student enters the labour market and brings in the knowledge that they have obtained within the university. We distinguish between two types of human capital spill-overs: 1) the direct education of students who will add to the total stock of human capital when they enter the labour market (skill pool), 2) other labour market effects generated by universities by enriching the overall human capital in a place, which can be referred to as innovation-frontier extending effects (workforce pool). Both aspects of university activities are essential in the innovative capacity of regions and countries (Interim report, 2015, p. 10, 26).

These two types of human capital spill-overs can be narrowed down further. We have identified four dimensions of university activities in which universities can contribute to strengthen the human capital skill pool: leadership and governance, curricula, teaching and learning, internationalization of culture. Leadership and governance refers to the involvement of external actors in the leadership and governance of universities. This can create links between teaching, research and the societal engagement of universities and this could stimulate innovation. Another activity to increase the human capital skill pool is to include the private sector in the design of the curricula. This can create a workforce that has the skills to respond to the needs of society. In addition, universities could introduce entrepreneurship education and training based on experiential and action learning by engaging entrepreneurs. To conclude, an international environment can increase strategic thinking and create new research partnerships which in turn could create new ways of thinking that could stimulate innovation (Interim report, 2015, p. 31$32)$. 
The second type of human capital spill-overs are the university activities to increase the workforce pool. Four types of activities have been identified: graduates, mobility, lifelong learning and talent attraction. With the activity 'graduates' we mean that there is a match between the skills of a graduated student and their occupation. The second activity on mobility can influence the exchange of experiences can guide the research agenda and help non-academic partners solving their difficulties in their current innovation. Another activity related to lifelong learning and entails that current workers need to continuously update their skills to be able to respond to changing environments. To finalize, talent attraction and retention facilitate innovation through the availability of highly skilled and talented people (Interim report, 2015, p. 32-33).

\section{Framework}

The spill-overs we identified are structured around existing indicators that have been used to capture the sub-dimensions of university contribution to innovation capacity (Interim report, 2015, p. 33).

The use of indicators or measurements within the field of HE is nothing new as such. HE has always been involved in data and data analysis. The HE sector is a data-rich sector, and HE institutions generate and use a lot of this data every single day. There has been a drive to improve the kind of data that is available which is demonstrated by the various measurement activities to collect a wide-range of information on HE (Shacklock, 2016, p.3, 14).

Data on HEIs is collected for various purposes and for a wide range of organizations and individuals, including students, HE providers, governments and private companies. Moreover, these stakeholders also gather data on HEIs themselves. The potential of the data gathered on HEIs is to provide information and evidence that can inter alia support decision-making, regulating and funding.

HEIs are collecting vast amounts of data about their institutions every day. They gather data on students (e.g. courses undertaking, examination results), staff data (e.g. the number of people employed) and financial data (e.g. expenditure and income), amongst other (Shacklock, 2016, p. 16). One reason to collect these kind of data is for benchmarking purposes. Universities want to self-assess their institution, understand the process of strategy formulation and implementation, gain information to support decision-making processes and to identify areas of improvement, and to set targets for future developments.

In addition, government and government' departments collect data on HEIs. Annually, government departments gather data on research output and research income for the allocation of funding. For example, the Higher Education Research Data Collection (HERDC) in Australia comprises data on research income and research publications submitted by universities. The collection of HE research data is designed to ensure that the Australian Government's research grants are allocated in a transparent and fair way (About the HERDC, n.d.). 
On a higher level, the EU is too gathering data on HEIs, for similar purposes as governments and institutions themselves. The development and processes of the EHEA within the Bologna process made it necessary to collect data on trends and to compare economic and social data (EACEA P9 Eurydice, 2012, p.7). The EHEA has the objective to ensure more comparable, compatible and coherent systems of HE in Europe. To ensure this, quantitative data is collected on all main aspects of HE reforms, including mobility, internationalization, employability, student populations and expenditure on $\mathrm{HE}$ (European Commission/EACEA/Eurydice, 2015). The choice for indicators and data sources has been driven by the wish to provide evidence-based policies and to enable to compare countries and to exchange ideas and policy approaches (Eurostat, 2009, p.3).

These developments and processes within the EHEA resemble the employment of new public management (NPM) in HE which brought in new ideas, expectations and pressures. In general, NPM is described as a management culture that emphasizes the centrality of the citizen and accountability of results. One of the key characteristics on NPM that come to the fore within the EHEA is the focus on performance and accountability (Tolofari, 2005, p. 82, 86). In practice, this had led to a focus on effectiveness, delivery, measurement and outputs, which are all terms associated with NPM (Štech, 2012, p. 264). The shift from old public management to the new was further depicted by several characteristics discerned of NPM within HE, including: outputorientation, evaluation, monitoring and performance measurement (Brouker, De Wit \& Leisyte, 2015, p.6). These elements of NPM become clearly visible when we consider the policy making processes within the EHEA, where the tools of NPM such as benchmarks and sharing of information are being used (Lange \& Alexiadou, 2007, p.323-324).

\subsection{Open Method of Coordination}

The EHEA is embedded within an intergovernmental mean of governance in the EU, on the basis of the voluntarily cooperation of the member states. The EC does not have any formal competency in the field of HE. Each member state is responsible for the organization of its education and training systems. However, the EU does contribute to the development of quality education by encouraging cooperation between the EU member states and supporting their actions (EUR-lex, n.d.). This form of cooperation is referred to as the Open Method of Coordination (OMC). In short, the OMC is an EU policymaking process and is a form of soft governance to achieve convergence across EU goals through the exchange of good practices between EU countries (European Parliament, 2014).

The role of the EC in this process is to provide transparency and communications between the key actors (the member states), identifying good performance and weak performance, and sharing best practice from these good performers to help those performing more weakly. In short, it has a role in monitoring and surveillance (Prpic, 2014).

The policy making framework of the OMC also applies to the case of universities contributing to innovative capacity. Innovation policies pertain to the competence of national governments and university third mission policy is therefore reserved to national legislative competence (Granieri \& Renda, 2012, p.115). However, the 
challenges that HE are facing in the member states are more or less similar across the EU which makes the case that there are clear advantages in working together. One of these challenges is that Europe is facing a skills deficit and, during a time of economic crisis, highly-skilled individuals have a better chance of finding a job.

HE and its links with research and innovation play significant role in providing the highly skilled human capital and to educate citizens that Europe needs to create jobs and economic growth. The EU strategy for modernising HE within the EHEA explicitly mentions the important role of HE institutions in driving forward and maintain growth and links this to the role of HE institutions in research and innovation (European Commission, 2011, p.2-3). In addition, the Europe 2020 Strategy on Education and Training makes a strong case for the role of HE to enhance innovation to improve the overall knowledge capital endowments for growth and jobs (Council of the European Union, 2009). Moreover, emerging innovation policies of the EU recognize a central role for HE in innovation policies (Skills and education, n.d.).

It is therefore important to be able to analyse and measure in an appropriate fashion the way in which education, training and skills contribute to the capacity of society and the economy to innovate. Since the policy-making process of the OMC applies to HE and innovation policies, the purpose of measuring university contribution to innovation capacity is to assist and support national HE policy makers towards a situation where legislation and framework optimise the contribution across European HE as a whole.

The EC wants to raise the performance in innovation: increasing the contribution of European HE to innovation capacity to provide the human capital needed to increase the knowledge based-economy (European Commission, 2010). To determine the innovation performance of the EU member states, the European Innovation Score Board (EIS) has been developed in 2001 to assess the innovation performance. The EIS is a benchmarking tool and allows to the comparisons of the innovation performances of the EU member states (Schibany \& Streicher, 2008, p.2).

\subsection{European Innovation Scoreboard}

The EIS is at the moment the tool within European technology policy to measure the innovation performances of the EU member states. The EIS follows the structure of the OMC: it is a comparative assessment and allows one to identify the strengths and the weaknesses of the research and innovation systems (Hollanders, Es-Sadki \& Kanerva, 2015, p.7).

The EIS measurement framework is based on 25 indicators which are summarized into one composite indicator (aggregated statistics). The indicators are divided among three dimensions: enablers, firm activities and outputs. The indicators for the dimension 'enablers' focus on the main drivers of innovation performance that are external to the firm. Indicators within this dimension measure the availability of a skilled and educated workforce (e.g. doctorate graduates). The indicators for the dimension 'firm activities' focus on innovation activities within the firm. Indicators within this dimension measure firm investments (e.g. (non-) R\&D expenditure), linkages and entrepreneurship (e.g. copublications with public sector), and intellectual assets (e.g. PCT patent applications). 
The last dimension 'outputs' focuses on the effects of innovation activities of firms. Indicators within this dimension measure innovators (e.g. innovations within their organisations) and economic effects (e.g. license and patent revenues from selling technologies abroad) (Hollanders, Es-Sadki \& Kanerva, 2015, p.7-8).

The indicators used in this framework, indirectly, focus both on the second and third mission of HEIs and also focus on the two spill-overs we identified: knowledge transfer and human capital. We could argue that the EIS provides a comprehensive assessment for innovation performance, which could also be applied to HEIs (albeit slightly altered).

Even though the EIS is the most-used and well-known benchmarking tool to measure innovation performance across the EU member states, there have been discussions on the effectiveness on the list of indicators. One of the main critiques on the EIS is that the use of an aggregated indicator does not capture national differences. A composite indicator does not allow one to differentiate between structures of countries. Innovation policy needs to take into account the environment of a country (Schibany \& Streicher, 2008, p. 5-10, 19).

\subsection{New framework within the OMC}

Based on this limitation of the EIS, we propose a different indicator set that aims to capture the variability between national systems and to differentiate between performances between national systems with regard to universities contributing to innovation capacity.

We try to identify the kinds of university-derived outputs that provide for activities which will expand innovators' access to the innovation resources. Our focus on spill-overs: how do universities generate knowledge externalities that could contribute to innovation capacity? We will propose a set of indicators for future measurement of the innovation impacts of HE. This set of indicators will used within the OMC and should therefore be able, on the basis of benchmarking, to discern performances within European knowledge pools. We are concerned with measuring the contributions to European innovation capacity, although that might be at a pan-EU level, within member-states, within macroregions or even within localities, cities and rural areas (Interim Report, 2015, p. 12).

We will link our set of indicators to the theoretical underpinnings of knowledge exchange and human capital to the innovation capacities of HEIs. It is important to recognize that for an indicator set to work and function properly and to ultimately develop an effective $\mathrm{OMC}$, it is important that the indicators fulfil certain criteria. The first criteria to consider is that the indicators should be suitable. With suitability we mean that the indicator should allow for comparison between different systems and it should capture variability. Concerning the latter the indicators should be able to differentiate between performances in national systems. A good indicator is suitable when there is a good proportionality between the activity being measured and the overall characteristic being measured (Interim Report, 2015, p. 46).

The second criteria that the indicators should fulfil is that they are to be legitimate. This criteria only applies to the spill-overs related to human capital. It is important that the measures influence people's willingness to act (mobilization potential). If people believe 
that the indicators are good measures to measure innovation capacity, it will me more likely that they receive support as being good indicators. Member states have the competence to act and agreement on relevant indicators is necessary for implementation (Homeyer, Klasing \& Kraemer, 2004, p.12). On the basis of reports and articles we have read to compile a long list of indicators, we have identified three characteristics that support the legitimacy of an indicator. These three dimensions are:

1. Equipping: they should be related to the creation of university human capital (by providing students with the relevant skills and tools).

2. Empowering: they should be grounded through practical implementation and experience (having the opportunity to experience the tools in practice).

3. Engaging: they involve network/connection/interaction with business (external actors should be able to share their know-how in situations).

We need to ensure that the measures we select fulfil the two criteria we have identified: technical suitability and policy legitimacy. The indicators should be proxies that are measuring a concept in which an increase will be regarded as increased spill-over effects. Moreover, the proxies should give the suggestion that there is a university human capital that moves and creates an impact (an output), which should represent a real word activity, and in which business/innovators are interested (Interim Report, 2015, p.51).

\section{Conclusion}

Universities are increasingly expected to engage in innovation activities to contribute to the development of the economy and the society. Policy-makers are developing measures to determine the extent to which universities contribute to innovation and innovation growth. Measures already in place tend to put most emphasize on the second mission of HEIs by focusing on elements of R\&D. In addition, a well-used scoreboard has been developed to benchmark EU member states. The EIS measures the innovation performance of the EU member states by including 25 indicators to measure specific dimensions and these are then summarized into one composite indicator. The EIS includes indirectly the second and third mission of HEIs and the human capital and knowledge transfer spill-overs we have identified as relevant.

Nevertheless, these existing frameworks are limited in that they either tend to forget the third mission of HEI's or they neglect national differences. In light of these limitations we seek to develop an improved set of indicators to measure the contribution of universities to innovation capacity.

Universities can contribute to innovation capacity through various channels. We have identified two of these channels: knowledge transfer and human capital. These two types of spill-overs are generated by universities and could create resources that innovators can later exploit. The spill-overs can be structured around existing indicators that will be included in our proposed future set of indicators to measure innovation capacity. For our indicator set to work and function properly within the framework of the Open Method of Coordination, there are two types of criteria that need to be fulfilled. For the knowledge transfer indicators it is important that they are technically suitable and for the human 
capital indicators it is crucial that they fulfil the technical suitability and policy legitimacy criteria.

Based on this, we have made a first indicator selection for measuring the university contribution to innovation capacity. We have tried to ensure that the indicators balance the two types of spill-overs and their dimensions. In addition we have tried to assess their performance on their technical suitability and policy legitimacy. The proposed indicator set can be found in table 1 on the next page.

We would like to emphasize that this is a first attempt to develop an indicator set to improve the university contribution via the $\mathrm{OMC}$. More research needs to be done regarding the feasibility of these indicators. 
Table 1: Proposed indicator set to measure how universities contribute to innovation capacity via spill-overs

\begin{tabular}{|c|c|c|c|c|}
\hline & University activities & Proposed indicators & $\begin{array}{l}\text { Technical } \\
\text { Suitability }\end{array}$ & $\begin{array}{l}\text { Policy } \\
\text { legitimacy }\end{array}$ \\
\hline \multirow{4}{*}{ 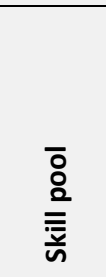 } & Leadership/Governance & 1. \% extl members on university bodies (senate/ council/ court), Oversight/ faculty/ consultative Board & $\checkmark \checkmark$ & $\checkmark \checkmark \checkmark$ \\
\hline & Curricula & $\begin{array}{l}\text { 2. Participation of non-academic agents in the definition of curriculum development (level measure) } \\
\text { 3. \% of academics teaching extra-curricular courses on creativity, innovation and/or entrepreneurship }\end{array}$ & $\begin{array}{l}\checkmark \checkmark \\
\checkmark \checkmark\end{array}$ & $\begin{array}{l}\checkmark \checkmark \\
\checkmark \checkmark\end{array}$ \\
\hline & Teaching \& Learning & $\begin{array}{l}\text { 4. \% non academic staff with validated qualification or experience in entrepreneurship training } \\
\text { 5. \% staff teaching entrepreneurship courses }\end{array}$ & $\begin{array}{l}\checkmark \checkmark \\
\checkmark \checkmark\end{array}$ & $\checkmark$ \\
\hline & Internationalization & 6. Number of ECTS awarded to international exchange students & $\checkmark \checkmark$ & $\checkmark$ \\
\hline \multirow{4}{*}{ 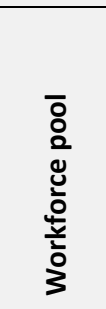 } & Graduates & $\begin{array}{l}\text { 7. \% of former students (by cohort) who are employed within one year after graduation } \\
\text { 8. \% former students (by cohort) employed in an occupation that matches their degree within one year after graduation }\end{array}$ & $\begin{array}{l}\checkmark \checkmark \\
\checkmark \checkmark\end{array}$ & $\begin{array}{l}\checkmark \checkmark \\
\checkmark \checkmark\end{array}$ \\
\hline & Mobility & $\begin{array}{l}\text { 9. \% of students taking ECTS in external settings (i.e. private sector) } \\
\text { 10. \% of Ph.D. training time spent in the non-academic sector }\end{array}$ & $\begin{array}{l}\checkmark \\
\checkmark \\
\checkmark\end{array}$ & $\begin{array}{l}\checkmark \checkmark \\
\checkmark \checkmark \checkmark\end{array}$ \\
\hline & Lifelong learning & 11. \% academics teaching in courses demanded by non-academic agents (firms, sector, NGOs,...) & $\checkmark \checkmark \checkmark$ & $\checkmark \checkmark$ \\
\hline & Talent retention & $\begin{array}{l}\text { 12. \% students (by cohort) who moved to the region (travel-to-study area) of the university } \\
\text { 13. \% students (by cohort) who stay in the region (travel-to-study area) of study within one year after graduation }\end{array}$ & $\begin{array}{l}\checkmark \checkmark \\
\checkmark \checkmark\end{array}$ & $\begin{array}{lll} \\
\checkmark \\
\checkmark \checkmark\end{array}$ \\
\hline \multirow{4}{*}{ 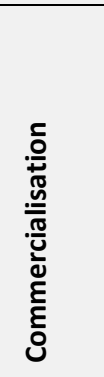 } & IP Income & 14. IP revenues (licence) & $\checkmark \checkmark$ & $\checkmark \checkmark$ \\
\hline & Spin-off activity & $\begin{array}{l}\text { 15. Estimated employment and turnover of active HEI spin-offs } \\
\text { 16. Estimated employment and turnover of Students start-ups - including founders' academic background } \\
\text { 17. Industry involvement in Students start-ups: estimated funding; licencing of the invention to industry } \\
\text { 18. Number of STEM grads; Number of Total grads; Number of total staff with Postgrad degree }\end{array}$ & $\begin{array}{l}\checkmark \checkmark \\
\checkmark \checkmark\end{array}$ & $\begin{array}{l}\checkmark \checkmark \\
\checkmark \checkmark\end{array}$ \\
\hline & $\begin{array}{l}\text { Infrastructure for } \\
\text { commercialisation }\end{array}$ & $\begin{array}{l}\text { 19. Presence of }(\mathrm{Y} / \mathrm{N}) \text { or Number }(\mathrm{N}) \text { in university: On-campus incubators }(\mathrm{N}) \text {; Small office areas }(\mathrm{Y} / \mathrm{N}) \text {; Other incubators } \\
\text { locally }(\mathrm{N}) \text {; Science parks }(\mathrm{N}) \text {; Entrepreneurship training }(\mathrm{Y} / \mathrm{N}) \text {; Seed corn investment }(\mathrm{Y} / \mathrm{N}) \text {; Venture capital }(\mathrm{Y} / \mathrm{N}) \text {; } \\
\text { Business advice }\end{array}$ & $\checkmark \checkmark$ & $\checkmark \checkmark \checkmark$ \\
\hline & Incubating facilities & 20. Tenant firms finance raised & $\checkmark$ & $\checkmark$ \\
\hline \multirow{2}{*}{ 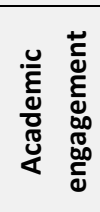 } & Collaborative R\&D & $\begin{array}{l}\text { 21. Income, total value, number of collaborative research involving public funding (SME, large firm, non-commercial) } \\
\text { 22. No of publications between academic researchers and industry } \\
\text { 23. University research funded by industry and by charities/foundations (number of projects, total value and \% of total) }\end{array}$ & $\begin{array}{l}\checkmark \checkmark \\
\checkmark \checkmark \checkmark \\
\checkmark \checkmark \checkmark\end{array}$ & $\begin{array}{l}\checkmark \checkmark \\
\checkmark \checkmark\end{array}$ \\
\hline & Consultancy & 24. Income, total value, number of contracts (by: SME , Non SME commercial, non-commercial) & $\checkmark \checkmark$ & $\checkmark \checkmark \checkmark$ \\
\hline \multirow{3}{*}{$\begin{array}{l}\text { Public } \\
\text { Engag } \\
\text { ement }\end{array}$} & Media engagement & 25. Number of media appearances by staff and by students & $\checkmark$ & $\checkmark \checkmark$ \\
\hline & Societal engagement & $\begin{array}{l}\text { 26. TM/SE objectives included in HE policy or strategies } \\
\text { 27. Numbers of academics engaged in Charities/Boards of Foundations/Schools }\end{array}$ & $\checkmark$ & - \\
\hline & Education outreach & 28. HEl budget allocated to educational outreach activities & $\checkmark \checkmark$ & $\checkmark \checkmark$ \\
\hline
\end{tabular}




\section{Acknowledgements}

The authors would like to thank Q-Plan International, Manchester Institute for Innovation Research - University of Manchester, LaSapienza - University of Rome and the Institute for Innovation and Knowledge Management - INGENIO (CSIC-UPV) for their contributions to the research project. 


\section{References}

Brennan, J., King, R., \& Lebeau, Y. (2004). The Role of Universities in the Transformation of Societies: An International Research Project. Center for HE Research and Information, the Open University, London. Available online at https://www.open.ac.uk/cheri/documents/transf-final-report.pdf

Broucker, B., De Wit, K., \& Leisyte, L. (2015). New Public Management or New Public Governance for the HE sector? An international comparison. EGPA Annual Conference 2015, 26-28 August -Toulouse, France. PSG VIII: Public Governance of Societal Sectors. Available online at https://lirias.kuleuven.be/bitstream/123456789/506994/1/paper+EGPA_Broucker_De+Wit_Le isyte_final.pdf

Council of the European Union (2009). Council conclusions of 12 May 2009 on a strategic framework for European cooperation in education and training ('ET 2020'). Available online at http://eur-lex.europa.eu/legalcontent/EN/TXT/PDF/?uri=CELEX:52009XG0528\%2801\%29\&from=EN

CEDEFOP (2008). Mind the gap: Europe's potential skills deficit. Available online at www.cedefop.europa.eu/files/BN_2008_09_en.pdf

Daud, S., Rahim, R.E.A., \& Alimun, R., (2008). Knowledge Creation and Innovation in Classroom. Available online at http://waset.org/publications/15319/knowledge-creation-and-innovationin-classroom

David, P.A., \& Metcalfe, S. (2007). Universities must contribute to enhancing Europe's innovative performance. Knowledge Economists' Policy Brief $\mathrm{n}^{\circ} 2$ October 2007. Available online at http://ec.europa.eu/invest-inresearch/pdf/download_en/knowledge_economists_policy_brief2_final.pdf

EACEA P9 Eurydice (2012). The European HE Area in 2012: Bologna Process Implementation Report. Available online at http://www.ehea.info/uploads/\%281\%29/bologna\%20process\%20implementation\%20report .pdf

EUR-lex (n.d.). Glossary of summaries: education. Retrieved from http://eurlex.europa.eu/summary/glossary/education.html

European Commission (n.d.). SKILLS MISMATCHES AND LABOUR MOBILITY. Retrieved from http://ec.europa.eu/europe2020/pdf/themes/27_skills_gaps_and_labour_mobility_02.pdf

European Commission (2010). Europe 2020: Commission proposes new economic strategy in Europe. IP/10/225. Available online at http://europa.eu/rapid/press-release_IP-10-225_en.htm

European Commission (2011). Supporting growth and jobs - an agenda for the modernisation of Europe's HE systems. Available online at http://eur-lex.europa.eu/legalcontent/EN/TXT/PDF/?uri=CELEX:52011DC0567\&from=EN

European Commission (2013). The Survey of Adult Skills (PIAAC): Implications for education and training policies in Europe. Available online at http://ec.europa.eu/education/policy/strategicframework/doc/piaac_en.pdf 
European Commission/EACEA/Eurydice (2014). Modernisation of HE in Europe: Access, Retention and Employability 2014. Eurydice Report. Luxembourg: Publications Office of the European Union.

European Commission/EACEA/Eurydice (2015). The European HE Area in 2015: Bologna Process Implementation Report. Luxembourg: Publications Office of the European Union.

European Parliament (2014). At a glance: the Open Method of Coordination. Available online at http://www.europarl.europa.eu/EPRS/EPRS-AaG-542142-Open-Method-of-CoordinationFINAL.pdf

Eurostat (2009). The Bologna Process in HE in Europe: Key indicators on the social dimension and mobility. Available online at http://www.uis.unesco.org/Education/Documents/KS-78-09-653EN.pdf

Garcia-Fontes, W., \& Gonzalez, R. (2004). Spillovers at the Research Unit Level. Available online at http://www.eco.uc3m.es/temp/PatVal3.pdf

Granieri, M.,\& Renda, A. (2012). Innovation Law and Policy in the European Union: Towards Horizon 2020. Springer Science \& Business Media.

HERDC (n.d.). About the HERDC. Retrieved from: https://www.education.gov.au/higher-educationresearch-data-collection

Hollanders, H., Es-Sadki, N., \& Kanerva, M. (2015). Innovation Union Score Board 2015. Available online at http://ec.europa.eu/growth/industry/innovation/facts-figures/scoreboards/files/ius2015_en.pdf

Homeyer, I., Klasing, A., \& Kraemer, R.A. (2004). Exploring the EU Open Method of Co-ordination. Available online at http://eucenter.wisc.edu/OMC/Papers/Other/environment.pdf

Interim report (2015). Study on measuring the contribution of HE to innovation capacity in the EU.

Izsak, K., Markianidou, P., Lukach, R., Wastyn, A. (2013). The impact of the crisis on research and innovation policies. Study for the European Commission DG Research by Technopolis Group Belgium and Idea Consult. Available online at https://ec.europa.eu/research/innovationunion/pdf/expert-groups/ERIAB_pb-Impact_of_financial_crisis.pdf

Lange, B., \& Alexiadou, N. (2007). New Forms of European Union Governance in the Education Sector? A Preliminary Analysis of the Open Method of Coordination. European Educational Research Journal 6 (4), pp. 321-335.

DOI: $10.2304 /$ eerj.2007.6.4.321

Levy, C. \& Hopkins, L. (2010). Shaping Up For Innovation: Are we delivering the right skills for the 2020 knowledge economy? Available online at http://www.theworkfoundation.com/assets/docs/publications/skills\%20report\%20\%20final.pdf

Marmolejo, F., \& Puukka, J. (2006). SUPPORTING THE CONTRIBUTION OF HE TO REGIONAL DEVELOPMENT: LESSONS LEARNED FROM AN OECD REVIEW OF 14 REGIONS THROUGHOUT 12 COUNTRIES. UNESCO Forum on HE, Research and Knowledge. Available online at http://portal.unesco.org/education/fr/files/51664/11634949875MarmolejoPuukkaEN.pdf/MarmolejoPuukka-EN.pdf

Mills, J., Platts, K., \& Bourne, M. (2003). Applying resource-based theory: methods, outcomes and utility for managers. The International Journal of Operations and Production Management 23 (2), pp 148-166. 
Pillay, P. (2010). HE and Economic Development: Literature Review. Wynberg: Centre for HE Transformation (CHET). Available online at http://chet.org.za/files/uploads/reports/Pillay\%202010\%20HE\%20and\%20Economic\%20Dev elopment\%20Literature\%20Review.pdf

Prpi, M. (2014). The Open Method of Coordination. Available online at http://www.europarl.europa.eu/RegData/etudes/ATAG/2014/542142/EPRS_ATA\%282014\%2 9542142_EN.pdf

Santema, S.C. \& Van de Rijt, J. (1999). EEN RESOURCE-BASED PORTFOLIOBENADERING: STRATEGIEËN OP BASIS VAN DE RESOURCE-BASED VIEW. Bedrijfskunde : Tijdschrift voor Modern Management 71 (4) , pp. 53-58.

Schinbany, A., \& Streicher, G. (2008). How not to compare innovation performance: A critical assessment of the European Innovation Scoreboard. Conference paper for the 2nd PRIME Indicators Conference on STI Indicators for Policy. Addressing New Demands of Stakeholders.

Shacklock, X. (2016). From bricks to clicks: the potential of data and analytics in HE. London: the HE Commission. Available online at

http://www.policyconnect.org.uk/hec/sites/site_hec/files/report/419/fieldreportdownload/fr ombrickstoclicks-hecreportforweb.pdf

Skills and education (n.d.). Retrieved from http://ec.europa.eu/growth/sectors/rawmaterials/specific-interest/skills-education/index_en.htm

Smart Specialization Platform (2011). Connecting Universities to Regional Growth: A Practical Guide. Available online at http://ec.europa.eu/regional_policy/sources/docgener/presenta/universities2011/universities 2011_en.pdf

Smith, E.A. (2001). The role of tacit and explicit knowledge in the workplace. Journal of Knowledge Management 5 (4), pp. 311-321.

Štech, S. (2012). The Bologna Process as a New Public Management Tool in HE. Journal of pedagogy 2 (2), pp. 263-282. DOI: 10.2478/v10159-011-0013-1

Tolofari, S. (2005). New Public Management and Education. Policy Futures in Education 3 (1), pp. 75-89.

Veugelers, R. (2014). The contribution of academic research to innovation and growth. Working Paper no 7. Available online at http://www.foreurope.eu/fileadmin/documents/pdf/Workingpapers/WWWforEurope_WPS_n o071_MS65.pdf

Veugelers, R., \& Del Rey, E (2014). The contribution of universities to innovation, (regional) growth and employment. European Expert Network on Economics of Education (EENEE) 
The Center for Higher Education Policy Studies (CHEPS) is a research institute (WHW, Article 9.20) located in the Faculty of Behavioural and Management Sciences within the University of Twente, a public university established by the Dutch government in 1961. CHEPS is a specialized higher education policy centre that combines basic and applied research with education, training and consultancy activities.

http://www.utwente.nl/bms/cheps/ 